\title{
Simultaneous Flow Injection Determination of Acetylcholine and Choline Based on Luminol Chemiluminescence in a Micellar System with On-Line Dialysis
}

\author{
Takashi HaSEbe, Junko Nagao and Takuji KawaShIMA ${ }^{\dagger}$ \\ Laboratory of Analytical Chemistry, Department of Chemistry, University of Tsukuba, \\ Tsukuba 305, Japan
}

\begin{abstract}
A simultaneous flow injection method (FIA) was developed for the determination of acetylcholine and choline. This method is based on the determination of hydrogen peroxide $\left(\mathrm{H}_{2} \mathrm{O}_{2}\right)$ produced from acetylcholine and choline by enzyme reactions. The determination of $\mathrm{H}_{2} \mathrm{O}_{2}$ was carried out by $\mathrm{Co}$ (II)-catalyzed luminol chemiluminescence (CL) reaction. The addition of sodium dodecylsulfate (SDS) in this CL system enhanced the CL intensity and sodium hydrogencarbonate showed an activating effect on the catalysis of $\mathrm{Co}(\mathrm{II})$ on the $\mathrm{CL}$ reaction. Interference of albumin for the CL reaction was removed by introducing an on-line dialysis unit and anion exchange column in the FIA system. A $10^{-6} \mathrm{~mol} \mathrm{dm}^{-3}$ level of acetylcholine and choline can be determined at a rate of 6 samples per hour (12 peaks). The method was successfully applied to the determination of acetylcholine and choline in a culture medium.
\end{abstract}

Keywords Flow injection analysis, micelle-enhanced luminol chemiluminescence, enzyme reaction, acetylcholine esterase, choline oxidase, $\mathrm{Co}$ (II) catalysis

Acetylcholine is one of the neurotransmitters in the central and peripheral nervous systems and is converted to choline as a metabolite with the action of acetylcholine esterase (AChE). Then the choline produced is successively hydrolyzed by choline oxidase $(\mathrm{ChO})$ to betaine and hydrogen peroxide $\left(\mathrm{H}_{2} \mathrm{O}_{2}\right)$, consuming any dissolved oxygen in the sample solution.

$$
\begin{aligned}
& \mathrm{ACh}+\mathrm{H}_{2} \mathrm{O} \stackrel{\text { AChE }}{\longrightarrow} \mathrm{Ch}+\text { Acetic acid } \\
& \mathrm{Ch}+2 \mathrm{O}_{2}+\mathrm{H}_{2} \mathrm{O} \stackrel{\text { ChO }}{\longrightarrow} \text { Betaine }+2 \mathrm{H}_{2} \mathrm{O}_{2}
\end{aligned}
$$

Recently pharmacological effects of acetylcholine and choline were reported in connection with the development of medication for Alzheimer-type senile dementia. ${ }^{1}$ Therefore, the determination of trace amounts of acetylcholine and choline has considerable importance in medical research and clinical diagnoses. Various methods for acetylcholine and choline have been reported, such as HPLC ${ }^{2-5}$, spectrophotometry ${ }^{6}$, electrochemical method including enzyme sensor ${ }^{7-12}$, peroxyoxalate $\mathrm{CL}$ method $^{13}, \mathrm{GC} / \mathrm{MS}^{14}, \mathrm{LC} / \mathrm{MS}^{15}$ and radioenzymatic method. ${ }^{16,17}$ However, these methods are laborious, time-consuming, lack sensitivity and need expensive apparatus. A simple and sensitive method for both substrates is thus required.

\footnotetext{
† To whom correspondence should be addressed.
}

On the other hand, the CL method has been known as a sensitive and simple one for the determination of $\mathrm{H}_{2} \mathrm{O}_{2}$ and various biological substances. ${ }^{18}$ The present paper describes the simultaneous flow injection analysis (FIA) of acetylcholine and choline based on the luminol CL reaction in a micellar system with on-line dialysis ${ }^{19-21}$, and on the determination of $\mathrm{H}_{2} \mathrm{O}_{2}$ produced from acetylcholine and choline by enzyme reactions according to Eqs. (1) and (2).

In the determination of acetylcholine, coexisting choline was removed after conversion to $\mathrm{H}_{2} \mathrm{O}_{2}$ by reaction (2), followed by the decomposition of $\mathrm{H}_{2} \mathrm{O}_{2}$ to oxygen by the action of catalase (CAT) according to

$$
2 \mathrm{H}_{2} \mathrm{O}_{2} \stackrel{\text { CAT }}{\longrightarrow} \mathrm{O}_{2}+2 \mathrm{H}_{2} \mathrm{O}
$$

Then acetylcholine was subsequently hydrolyzed to $\mathrm{H}_{2} \mathrm{O}_{2}$ via Eqs. (1) and (2). In the determination of choline, only the second enzyme reaction (Eq. (2)) was used. The concentrations of $\mathrm{H}_{2} \mathrm{O}_{2}$ produced from acetylcholine and choline were successively determined by $\mathrm{Co}$ (II)catalyzed luminol $\mathrm{CL}$ reaction. ${ }^{22,23}$ To improve the sensitivity of the method, a miceller system of sodium dodecylsulfate (SDS) as an anionic surfactant was employed in the CL reaction. ${ }^{24}$ In addition, a dialyzer and an anion exchange resin column were introduced into the FIA system to remove the interference of diverse compounds such as albumin, ascorbic acid, uric acid, 


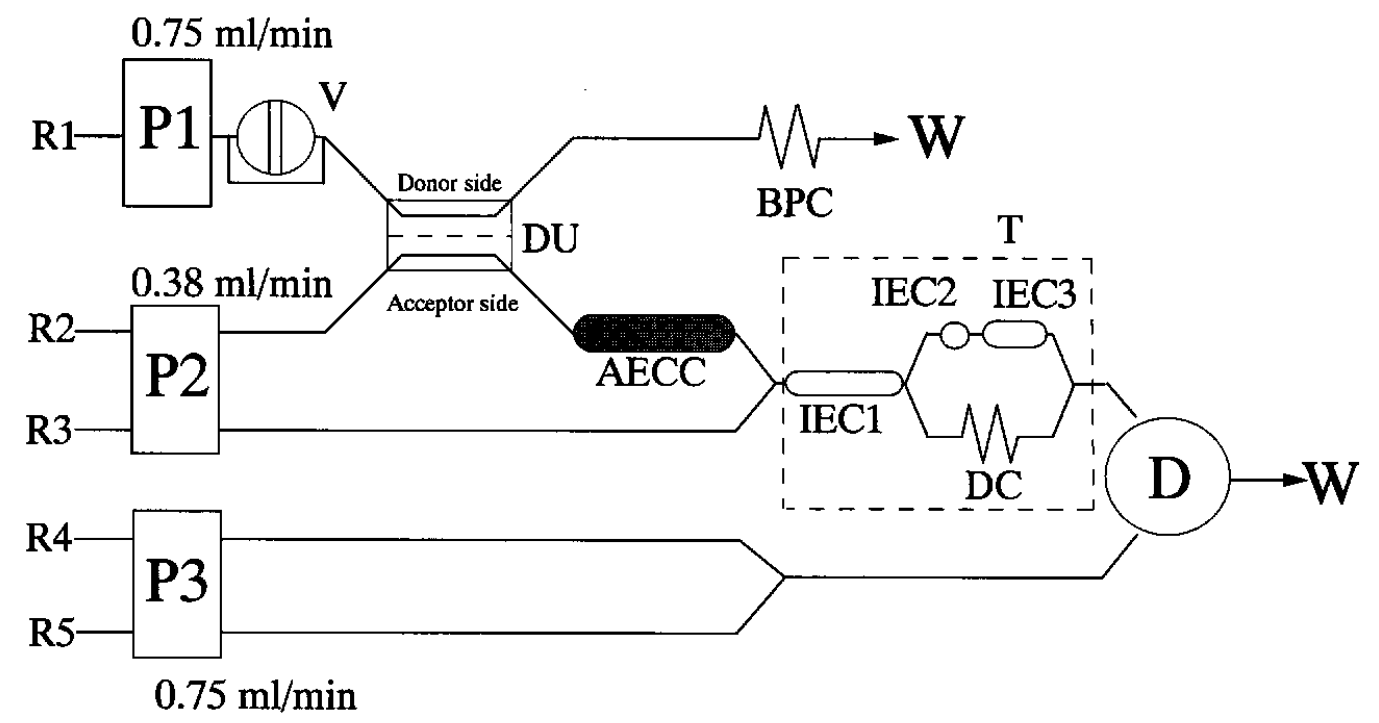

Fig. 1 Flow diagram of FIA for the simultaneous determination of acetylcholine and choline. R1, water; R2, disodium hydrogenphosphate- $\mathrm{NaOH}$ buffer $\left(2.0 \times 10^{-2} \mathrm{~mol}\right.$ $\mathrm{dm}^{-3}$, pH 11); R3, phosphate buffer $\left(2.0 \times 10^{-2} \mathrm{~mol} \mathrm{dm}^{-3}, \mathrm{pH} 7\right)$; R4, Co(II) $\left(1.0 \times 10^{-6}\right.$ mol dm$\left.m^{-3}\right) /$ hydrochloric acid $\left(1.0 \times 10^{-2} \mathrm{~mol} \mathrm{dm}^{-3}\right) ; \mathrm{R} 5$, luminol $\left(5.0 \times 10^{-7} \mathrm{~mol} \mathrm{dm}^{-3}\right) /$ sodium hydrogencarbonate $\left(0.1 \mathrm{~mol} \mathrm{dm}^{-3}\right) / \mathrm{SDS}(0.18 \mathrm{wt} \%) /$ borate buffer $(0.1 \mathrm{~mol}$ $\mathrm{dm}^{-3}$ ); P1-P3, pump; V, sample injector (sample volume $800 \mu 1$ ); DC, delay coil ( $12 \mathrm{~m}$ long, $0.5 \mathrm{~mm}$ i.d.); BPC, back pressure coil ( $30 \mathrm{~m}$ long, $0.5 \mathrm{~mm}$ i.d.); DU, dialyzer; $\mathrm{T}$, thermostated bath $\left(37^{\circ} \mathrm{C}\right)$; $\mathrm{D}, \mathrm{CL}$ detector; $\mathrm{W}$, waste; $\mathrm{AECC}$, anion exchange column (7.5 cm long, $2 \mathrm{~mm}$ i.d.); IEC1 - IEC3, immobilized enzyme column.

histidine and tryptophan on the CL reaction.

\section{Experimental}

\section{Reagents}

All chemicals used were of analytical reagent grade. Water was obtained from a Milli-Q Plus water purification system (Millipore Co.). Luminol from Kanto Chemical Co. was used without further purification. A luminol stock solution $\left(1.0 \times 10^{-2} \mathrm{~mol} \mathrm{dm}^{-3}\right)$ was prepared by dissolving $0.177 \mathrm{~g}$ of the compound in $100 \mathrm{ml}$ of borate buffer solution $\left(0.1 \mathrm{~mol} \mathrm{dm}^{-3}, \mathrm{pH} \mathrm{11}\right)$. SDS was obtained from Tokyo Kasei Co. and a working solution $(0.18 \mathrm{wt} \%)$ was prepared daily by dissolving weighed amounts of the surfactant in borate buffer solution. A Co(II) stock solution $\left(1.0 \times 10^{-2} \mathrm{~mol} \mathrm{dm}^{-3}\right)$ was prepared by dissolving $0.238 \mathrm{~g}$ of cobalt(II) chloride hexahydrate in $100 \mathrm{ml}$ of $0.1 \mathrm{~mol} \mathrm{dm}^{-3}$ hydrochloric acid. Each working solution of $\mathrm{Co}$ (II) $\left(1.0 \times 10^{-6} \mathrm{~mol} \mathrm{dm}^{-3}\right)$ was prepared from the stock solution by suitable dilution with $1.0 \times 10^{-2} \mathrm{~mol} \mathrm{dm}^{-3}$ hydrochloric acid. An acetylcholine stock solution $\left(1.0 \times 10^{-2} \mathrm{~mol} \mathrm{dm}^{-3}\right)$ was prepared by dissolving $0.182 \mathrm{~g}$ of acetylcholine chloride from Sigma Chemical in $100 \mathrm{ml}$ of phosphate buffer solution (2.0 $\times 10^{-2} \mathrm{~mol} \mathrm{dm}^{-3}, \mathrm{pH} 8.0$ ). A choline stock solution $\left(1.0 \times 10^{-2} \mathrm{~mol} \mathrm{dm}^{-3}\right)$ was prepared by dissolving $0.140 \mathrm{~g}$ of choline chloride from Kanto Chemical Co. in $100 \mathrm{ml}$ of phosphate buffer solution $\left(2.0 \times 10^{-2} \mathrm{~mol} \mathrm{dm}^{-3}, \mathrm{pH} 8.0\right)$. Working solutions of acetylcholine and choline were prepared daily by suitable dilution with water. AChE (EC 3.1.1.7, Type VI-S, electric eel, $260 \mathrm{IU} / \mathrm{mg}$ ) and CAT (EC 1.11.1.6, bovine liver, $5000-9000$ units $/ \mathrm{mg}$ ) were obtained from Wako Pure Chemical Co. ChO (from alcaligenes sp., $12.7 \mathrm{IU} / \mathrm{mg}$ ) was obtained from Toyobo Co.

\section{Preparation of enzyme reactor}

Enzymes (AChE, ChO, CAT) were immobilized respectively on controlled pore glass (CPG) by crosslinking with glutaraldehyde, as described previously. ${ }^{25}$ $\operatorname{AChE}(100 \mathrm{U}), \mathrm{ChO}(100 \mathrm{U})$ and CAT $\left(2.5 \times 10^{4} \mathrm{U}\right)$ were loaded onto CPG $(1 \mathrm{ml})$ with pore sizes of $170 \AA, 350 \AA$ and $700 \AA$, respectively. The excess enzymes were removed by washing with phosphate buffer solution $\left(2.0 \times 10^{-2} \mathrm{~mol} \mathrm{dm}^{-3}, \mathrm{pH} \mathrm{8.0}\right)$. Immobilized enzymes were packed into Teflon tubing ( $2 \mathrm{~mm}$ i.d.) with a line filter as a stopper at one end. Enzyme column lengths were $12 \mathrm{~cm}$ for $\mathrm{ChO}, 1 \mathrm{~cm}$ for CAT, $4 \mathrm{~cm}$ for a mixture of equal amounts of $\mathrm{AChE}$ and $\mathrm{ChO}$. These columns were introduced into the FIA system. Immobilized enzymes could be used for one month with at least 900 runs, although the activity of the mixed enzymes decreased to ca. $80 \%$ of the initial one. When the enzyme columns filled with the phosphate buffer solution were stored in the refrigerator at $4^{\circ} \mathrm{C}$, no significant decrease of activity was observed.

\section{Apparatus}

A schematic flow diagram for the determination of 
acetylcholine and choline is shown in Fig. 1. The system was assembled from Teflon tubing $(0.5 \mathrm{~mm}$ i.d.) and constructed using three double-plunger micropumps (Sanuki Kogyo, DMX-2000), a six-way rotary valve (V) (GL Science, MPV-6) with a sampling loop $(800 \mu \mathrm{l})$, a circulating thermostated bath (T) (TAITEC DX-100), a CL detector (D) (Soma S-3400) with a spiral flow-cell $(200 \mu \mathrm{l})$ and a recorder (Chino EB 22005). In the flow system, a dialyzer (DU) consisted of two Teflon blocks $(1.0 \times 3.0 \times 1.3 \mathrm{~cm})$ with an ADVANTEC PO200 ultrafilter $(0.5 \times 1.5 \mathrm{~cm}$, molecular weight cut off of 20000$)$ as a dialysis membrane was introduced. A back-pressure coil (BPC) $(30 \mathrm{~m}, 0.5 \mathrm{~mm}$ i.d.) was attached at the waste outlet to generate higher pressure on the donor side than that on the acceptor side. The low molecular weight compounds were extracted from donor side to acceptor side by using the pressure difference. An anion exchange column ( $2 \mathrm{~mm}$ i.d., $7.5 \mathrm{~cm}$ long) (AECC) packed with BIO-RAD AG1-X4 anion exchange resin was introduced. Immobilized enzyme columns of $\mathrm{ChO}$ (IEC1), CAT (IEC2) and a mixture of $\mathrm{ChO}$ and AChE (IEC3) were then attached to AECC. A pH/mV meter (Iwaki M-120) was also used.

\section{Procedure}

In the flow system (Fig. 1), a carrier (R1, water), a disodium hydrogenphosphate- $\mathrm{NaOH}$ buffer $(\mathrm{R} 2,2.0 \times$ $10^{-2} \mathrm{~mol} \mathrm{dm}^{-3} \mathrm{pH} \mathrm{11.0)}$, a phosphate buffer (R3, 2.0 $\times$ $10^{-2} \mathrm{~mol} \mathrm{dm}^{-3} \mathrm{pH} \mathrm{7.0)}$, a $\mathrm{Co}$ (II) $\left(1.0 \times 10^{-6} \mathrm{~mol} \mathrm{dm}^{-3}\right)$ solution in hydrochloric acid $\left(1.0 \times 10^{-2} \mathrm{~mol} \mathrm{dm}^{-3}\right)(\mathrm{R} 4)$ as a catalyst on the $C L$ reaction and a mixed solution of luminol $\left(5.0 \times 10^{-7} \mathrm{~mol} \mathrm{dm}^{-3}\right)$, sodium hydrogencarbonate $\left(0.1 \mathrm{~mol} \mathrm{dm}^{-3}\right)$ and SDS $(0.18 \mathrm{wt} \%)$ in borate buffer solution ( $\mathrm{pH} 11.0$ ) (R5) were propelled by three doubleplunger pumps at a rate of 0.75 (P1, P3) and 0.38 (P2) $\mathrm{ml} \mathrm{min}^{-1}$. An $800 \mu$ l aliquot of a sample solution (a mixture of acetylcholine and choline) was injected into the carrier stream. In the dialyzer (DU), a sample solution is dialyzed to remove proteins. After dialyzing, other diverse compounds such as ascorbic acid, uric acid, histidine and tryptophan in the sample solution were removed by passing through AECC. Choline in solution after passing through AECC was converted to $\mathrm{H}_{2} \mathrm{O}_{2}$ at IEC1, and then the solution was separated into two flow lines. In one flow line, $\mathrm{H}_{2} \mathrm{O}_{2}$ produced from choline was decomposed at IEC2, while acetylcholine was converted to $\mathrm{H}_{2} \mathrm{O}_{2}$ via choline at IEC3. In another flow line, $\mathrm{H}_{2} \mathrm{O}_{2}$ produced from choline passed through the delay coil (DC, $0.5 \mathrm{~mm}$ i.d., $12 \mathrm{~m}$ long). The $\mathrm{CL}$ intensities corresponding to acetylcholine and choline were successively measured over the wavelnegth range $350-650 \mathrm{~nm}$ without wavelength discrimination by the CL detector and recorded on a recorder. The reaction temperature was maintained at $37^{\circ} \mathrm{C}$.

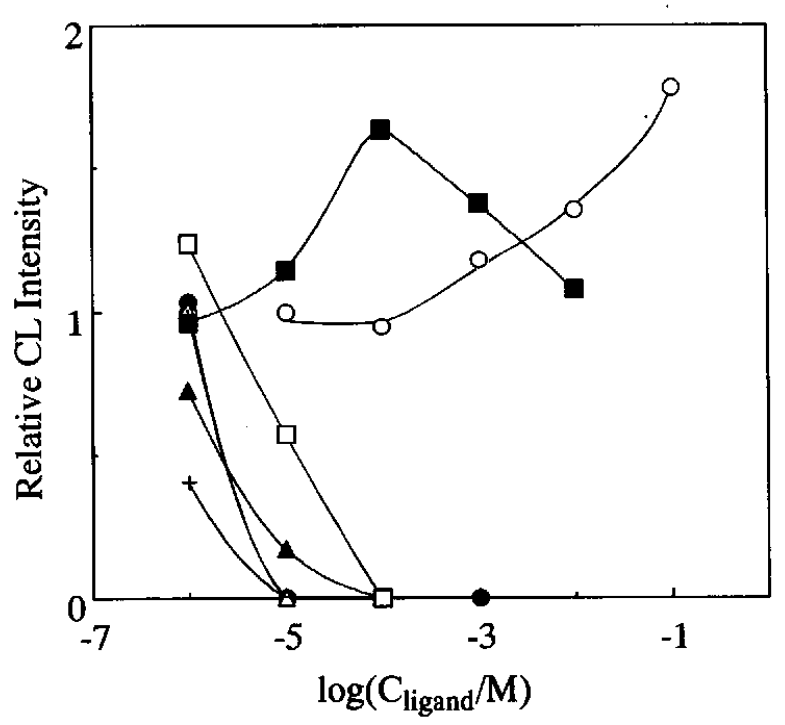

Fig. 2 Effect of ligands on the CL intensity. $C_{\mathrm{H} 2 \mathrm{O} 2}, 1.0 \times 10^{-6}$ mol dm${ }^{-3}$. O, $\mathrm{NaHCO}_{3} ; \square$, py; $\square$, bpy;, phen; $\triangle$, EDTA; $\Delta$, IDA; + , Tiron. Other conditions as in the text.

\section{Results and Discussion}

\section{Effect of reaction variables on the $C L$ reaction}

The catalytic effect of metal ions such as $\mathrm{Co}$ (II), $\mathrm{Cu}(\mathrm{II})$, $\mathrm{Fe}(\mathrm{II}), \mathrm{Ni}(\mathrm{II})$ and $\mathrm{Mn}$ (II) on the luminol- $\mathrm{H}_{2} \mathrm{O}_{2} \mathrm{CL}$ reaction has been reported: $\mathrm{Co}$ (II) showed the highest catalytic activity. ${ }^{22} \mathrm{Co}$ (II) was also selected as a catalyst in the present $\mathrm{CL}$ system. The effect of $\mathrm{Co}$ (II) concentration on the $\mathrm{CL}$ intensity was examined over the range $1.0 \times 10^{-8}$ to $1.0 \times 10^{-4} \mathrm{~mol} \mathrm{dm}^{-3}$. The CL intensity increased with increasing concentration of $\mathrm{Co}$ (II) up to $5.0 \times 10^{-6} \mathrm{~mol} \mathrm{dm}^{-3}$ and then decreased and became unstable at concentrations higher than $5.0 \times 10^{-6} \mathrm{~mol}$ $\mathrm{dm}^{-3}$. A $1.0 \times 10^{-6} \mathrm{~mol} \mathrm{dm}^{-3} \mathrm{Co}$ (II) concentration was selected, taking into account the $\mathrm{CL}$ intensity and reproducibility.

The effect of various ligands as activators on the catalysis of $\mathrm{Co}$ (II) on the CL reaction was examined. ${ }^{26}$ The ligands examined were ethylenediamine- $N, N, N^{\prime}, N^{\prime}$ tetraacetic acid (EDTA), iminodiacetic acid (IDA), pyridine (py), 2,2'-bipyridine (bpy), 1,10-phenanthroline (phen), 1,2-dihydroxybenzene-3,5-disulfonate (Tiron) and sodium hydrogencarbonate. Each ligand was mixed with the luminol solution and propelled from R3 into the system. The results are shown in Fig. 2. The CL intensities increased in the presence of hydrogencarbonate and py, respectively. In the presence of $0.1 \mathrm{~mol}$ $\mathrm{dm}^{-3}$ hydrogencarbonate and $1.0 \times 10^{-4} \mathrm{~mol} \mathrm{dm}^{-3} \mathrm{py}$, the $\mathrm{CL}$ intensities were enhanced 1.8 and 1.6 times larger than the values in their absence. Taking into account the sensitivity, we selected a $0.1 \mathrm{~mol} \mathrm{dm}^{-3}$ hydrogencarbonate for the procedure.

In the presence of hydrogencarbonate, the effect of the surfactant on the CL reaction was investigated. ${ }^{24,27,28}$ The surfactants examined were nonionic \{ TritonX-100 


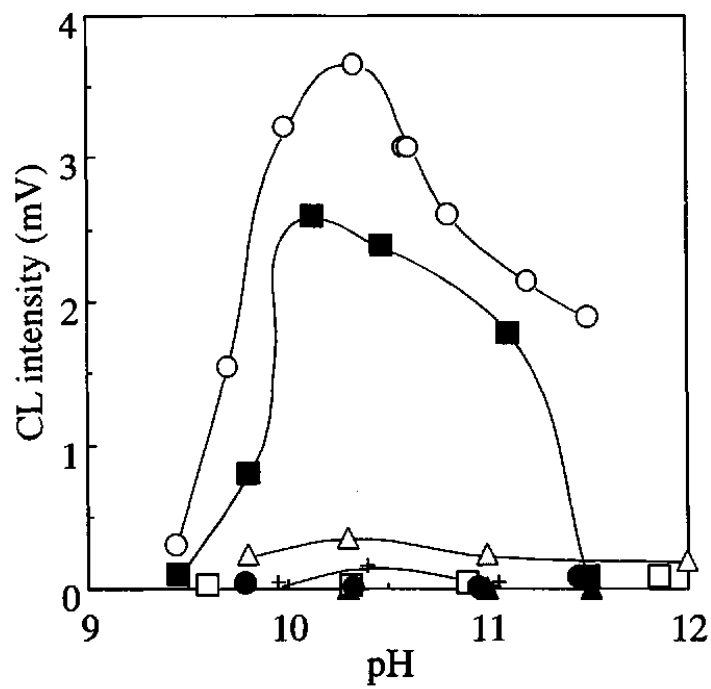

Fig. 3 Effect of surfactants on the $\mathrm{CL}$ intensity. $C_{\mathrm{H} 2 \mathrm{O} 2}$, $1.0 \times 10^{-6} \mathrm{~mol} \mathrm{dm}^{-3} ; C_{\text {surfactant }}, 5$ times of CMC. O, SDS; SDBS; +, DTAB; $\triangle$, CTAB; $\boldsymbol{\Delta}$, Zephiramine; $\square$, Brij35; $\square$, Triton $\mathrm{X}-100$. Other conditions as in the text.

(polyethylene glycol mono-4-octylpheny ether) and Brij 35 (polyoxyethylene-23-lauryl ether)\}, cationic \{Zephiramine (benzyldimethyltetradecylammonium chloride), DTAB (dodecyltrimethyl ammonium bromide) and CTAB (cetyltrimethyl ammonium bromide) $\}$ and anionic surfactants [SDS (sodium dodecyl sulfate) and SDBS (sodium dodecylbenzenesulfonate)\}. Each surfactant was mixed with a mixed solution of luminol and hydrogencarbonate, and the solution was propelled from R3 into the system. The concentration of surfactant in reservoir R3 was fixed at 5 times higher than the critical micelle concentration (CMC), considering the complete formation of micelle in the flow cell. The results are shown in Fig. 3. Among them, anionic surfactant SDS showed a large enhancement effect on the CL intensity. The CL intensity increased with increasing concentration of SDS up to $0.18 \mathrm{wt} \%$ and remained almost constant at concentrations higher than $0.18 \mathrm{wt} \%$. A $0.18 \mathrm{wt} \%$ SDS concentration was selected for the procedure. Maximum $\mathrm{CL}$ intensity was obtained at $\mathrm{pH}$ around 10.4. Thus, the $\mathrm{pH}$ of 10.4 was selected for the procedure.

\section{Optimization of enzyme reactor}

Preliminary experiments showed that the optimum $\mathrm{pH}$ of the enzyme reactions was about $8.0\left(2.0 \times 10^{-2} \mathrm{~mol}\right.$ $\mathrm{dm}^{-3}$ phosphate buffer). To decompose the $\mathrm{H}_{2} \mathrm{O}_{2}$ produced from coexisting choline, CAT column (IEC2) was first introduced into the flow system. By using the CAT column length of $1 \mathrm{~cm}(2 \mathrm{~mm}$ i.d.), no CL emission was detected even when $1 \times 10^{-1} \mathrm{~mol} \mathrm{dm}^{-3} \mathrm{H}_{2} \mathrm{O}_{2}$ was injected. Thus a column length of $1 \mathrm{~cm}$ was selected for CAT. It was found that choline is completely decomposed by two enzyme columns of IECl and IEC2. The effect of the dual enzyme column packed with an

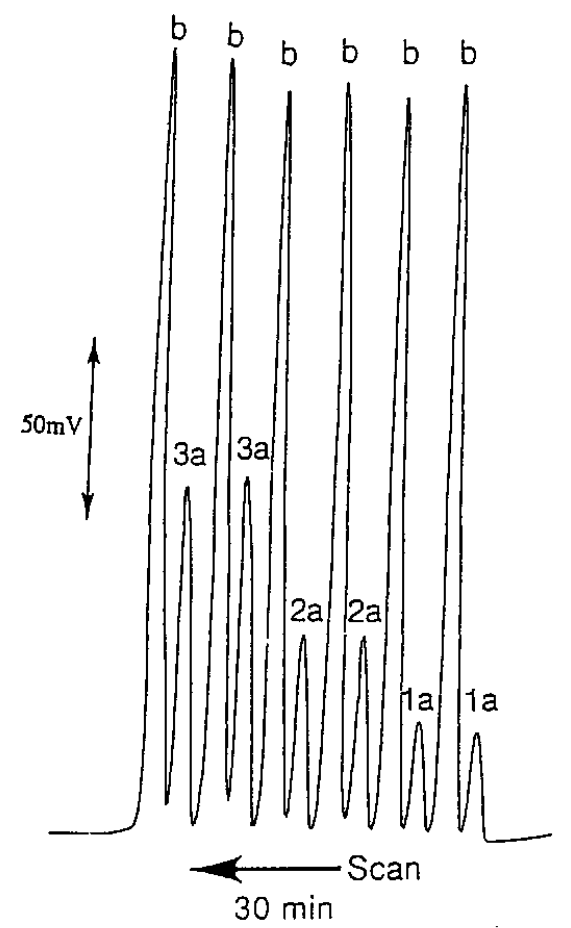

Fig. 4 Flow signals for the simultaneous determination of acetylcholine and choline. 1a: acetylcholine, $2.5 \times 10^{-6} \mathrm{~mol}$ $\mathrm{dm}^{-3} ; 2 \mathrm{a}$ : acetylcholine, $5.0 \times 10^{-6} \mathrm{~mol} \mathrm{dm}^{-3} ; 3 \mathrm{a}$ : acetylcholine, $10.0 \times 10^{-6} \mathrm{~mol} \mathrm{dm}^{-3}$; b: choline, $10.0 \times 10^{-6} \mathrm{~mol} \mathrm{dm}^{-3}$. Conditions as in Fig. 1.

equivalent mixture of immobilized $\mathrm{AChE}$ and $\mathrm{ChO}$ (IEC3) was examined on the conversion of acetycholine to $\mathrm{H}_{2} \mathrm{O}_{2}$ by injecting an aliquot $(800 \mu \mathrm{l})$ of $1 \times 10^{-5}$

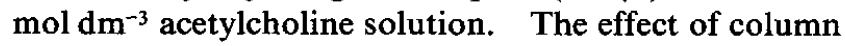
length of IEC3 was examined in the range $0.5-6 \mathrm{~cm}$. The CL intensity increased with increasing the column length until $4 \mathrm{~cm}$ and remained almost constant beyond this length. Thus, the column length was selected as $4 \mathrm{~cm}$. On the other hand, it was found that a $12 \mathrm{~cm}$ length of IECl was sufficient for the conversion of choline to $\mathrm{H}_{2} \mathrm{O}_{2}$.

\section{Calibration graphs for acetylcholine and choline}

Typical flow signals for simultaneous determination of acetylcholine and choline were obtained by injecting a $1.0 \times 10^{-5} \mathrm{~mol} \mathrm{dm}^{-3}$ of choline and various concentrations of $10^{-6} \mathrm{~mol} \mathrm{dm}^{-3}$ level of acetylcholine solutions into the carrier solution. The results are shown in Fig. 4. The linear calibration graphs were obtained over the range $5 \times 10^{-7}-1 \times 10^{-4} \mathrm{~mol} \mathrm{dm}^{-3}$ for acetylcholine and $5 \times$ $10^{-7}-5 \times 10^{-5} \mathrm{~mol} \mathrm{dm}^{-3}$ for choline, respectively. The detection limit $(S / N=3)$ of the present method was $8 \times 10^{-8} \mathrm{~mol} \mathrm{dm}^{-3}$ for acetylcholine and $5 \times 10^{-8} \mathrm{~mol} \mathrm{dm}^{-3}$ for choline, respectively. The assay speed was about 6 samples per hour (12 peaks per hour). The relative standard deviations were 2.6 and $2.7 \%$ for six successive determinations of $1 \times 10^{-5} \mathrm{~mol} \mathrm{dm}^{-3}$ of acetylcholine and choline, respectively. 
Table 1 Effect of diverse compounds $\left(1.0 \times 10^{-4} \mathrm{~mol} \mathrm{dm}^{-3}\right)$ on the determination of $1.0 \times 10^{-6} \mathrm{~mol} \mathrm{dm}^{-3}$ of hydrogen peroxide and acetylcholine

\begin{tabular}{lcc}
\hline \multirow{2}{*}{ Compounds added } & \multicolumn{2}{c}{ Relative CL intensity } \\
\cline { 2 - 3 } & $\mathrm{H}_{2} \mathrm{O}_{2}$ & Acetylcholine \\
\hline- & 100 & 100 \\
Fructose & 96.1 & 96.9 \\
Glucose & 99.0 & 103 \\
Urate (uric acid) & 3.25 & 23.9 \\
Ascorbate (ascorbic acid) & $\mathrm{ND}$ & $\mathrm{ND}$ \\
Glu & 96.1 & 98.4 \\
Gln & 95.2 & 95.4 \\
Gly & 101 & 104.7 \\
Arg & 86.5 & 89.1 \\
His & 26.8 & 23.8 \\
Trp & 22.0 & 24.4 \\
Phe & 97.2 & 96.4 \\
Met & 89.9 & 97.2 \\
Lys & 93.6 & 93.0 \\
Thr & 95.4 & 96.1 \\
Leu & 104 & 98.4 \\
Ile & 97.2 & 98.0 \\
Val & 96.3 & 100 \\
\hline
\end{tabular}

\section{Interference}

The effect of diverse compounds on the determination of $1.0 \times 10^{-6} \mathrm{~mol} \mathrm{dm}^{-3} \mathrm{H}_{2} \mathrm{O}_{2}$ and acetylcholine was examined without the anion exchange column. The results are summarized in Table 1. Ascorbic acid, uric acid, histidine and tryptophan at $1.0 \times 10^{-4} \mathrm{~mol} \mathrm{dm}^{-3}$ level gave a considerable negative error. These diverse compounds seem to act as inhibitors for the luminol CL reaction rather than enzyme reactions. This is due to the inhibition of luminol oxidation by the reducing power of these diverse compounds, trapping of active oxygen promoting the luminol $\mathrm{CL}$ reaction and lowering of catalytic activity by complexation of $\mathrm{Co}(\mathrm{II})$ with these compounds. ${ }^{29}$ Since these diverse compounds are easily transformed to anion forms in basic media, the use of the anion exchange column was attempted to remove these compounds in anionic form. The separation of these compounds from the mother liquid was conducted at pH 11.0 taking into account the fact that the isoelectric point and $\mathrm{p} K_{\mathrm{a} 3}$ of histidine are 7.59 and 9.19 , respectively. As a result, the effect of diverse ions were completely removed by using the anion exchange column length of more than $7.5 \mathrm{~cm}(2 \mathrm{~mm}$ i.d.). Since the activity of enzymes, however, rapidly decreased at $\mathrm{pH}$ around 11 , the buffer solution of $\mathrm{pH} 7.0$ in reservoir $\mathrm{R} 3$ was pumped in the front of IEC 1 to adjust the pH to 8.0. The effect of albumin existing abundantly in biological samples on the CL intensity was also examined. The results are given in Fig. 5. The CL intensity decreased rapidly with increasing albumin concentration and was not detected at higher concentration of $1 \mathrm{wt} \%$ of albumin. This is due to the lowering of catalytic activity of $\mathrm{Co}$ (II) by the formation of $\mathrm{Co}$ (II)-albumin complex, as the isotropic

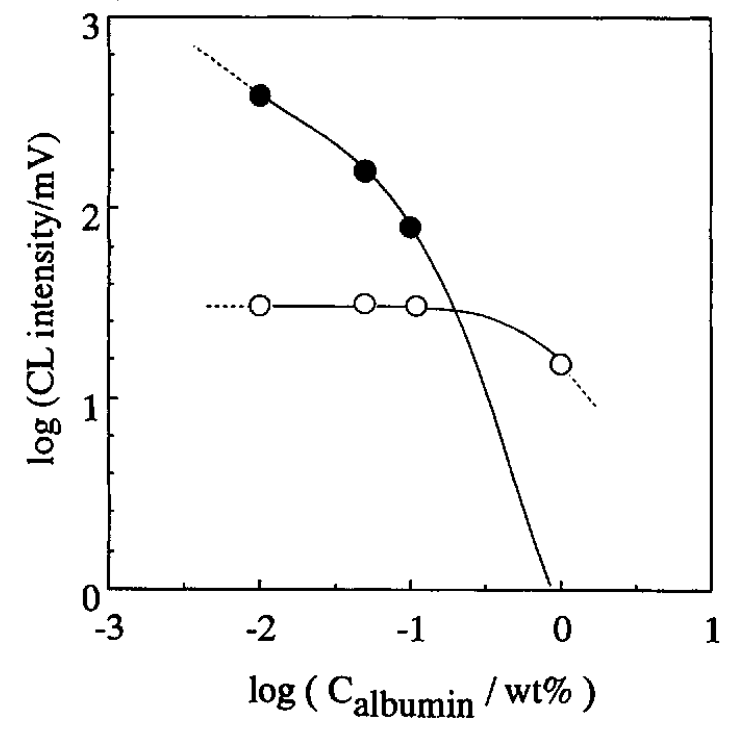

Fig. 5 Effect of albumin on the $\mathrm{CL}$ intensity. dialyzer; $\mathrm{O}$, with dialyzer. $C_{\mathrm{H} 2 \mathrm{O} 2}, 1.0 \times 10^{-6} \mathrm{~mol} \mathrm{dm}^{-3}$.

Table 2 Determination of acetylcholine and choline in ERDF culture medium

\begin{tabular}{ccc}
\hline $\begin{array}{c}\text { Acetylcholine added/ } \\
10^{-6} \mathrm{~mol} \mathrm{dm}^{-3}\end{array}$ & $\begin{array}{c}\text { Acetylcholine found/ } \\
10^{-6} \mathrm{~mol} \mathrm{dm}^{-3}\end{array}$ & $\begin{array}{c}\text { Recovery, } \\
\%\end{array}$ \\
$(10$ times dilution $)$ & ND & - \\
0 & 2.9 & 97 \\
3.0 & 5.0 & 100 \\
5.0 & 9.9 & 99 \\
10.0 & & \\
& Choline found/ & Recovery \\
Choline added/ & $10^{-6}$ mol dm ${ }^{-3}$ & $\%$ \\
$10^{-6}$ mol dm ${ }^{-3}$ & & \\
$(100$ times dilution $)$ & 2.2 & - \\
0 & 4.2 & 100 \\
2.0 & 6.5 & 108 \\
4.0 & 8.3 & 102 \\
6.0 & &
\end{tabular}

point of albumin is $4.8 .{ }^{30}$ Since albumin affects the CL intensity considerably, some removal processes of the albumin in biological samples are needed. In the proposed method, on-line dialysis unit was used in the FIA system. The results are shown in Fig. 5. Almost constant CL intensity was obtained in the concentration range $0.01-0.1 \mathrm{wt} \%$ of albumin, although the CL intensity became low.

\section{Determination of choline and acetylcholine in culture medium}

The flow injection system shown in Fig. 1 was applied to the determination of acetylcholine and choline in ERDF culture medium (Kyokuto Co.). The sample solution was diluted 10 or 100 times with purified water and then the diluted samples were injected into carrier 
stream. The analytical results obtained are summarized in Table 2. The results are in good agreement with the reference values. The recovery test showed good results in the ranges of $97-100 \%$ and $102-108 \%$ for acetylcholine and choline, respectively. The proposed method provides a simple and rapid determination of acetylcholine and choline with on-line pretreatment systems for the removal of proteins and diverse compounds. Thus, the present method is considered to be applicable to the determination of acetylcholine and choline in other biological samples.

\section{References}

1. M. Kubota, Farumashia, 28, 354 (1992).

2. T. Yao and M. Sato, Anal. Chim. Acta, 172, 371 (1985).

3. Y. Fujiki, Y. Ikeda, S. Okuyama, K. Tomoda, K, Ooshiro, H. Matsumura, T. Ito and T. Yamauchi, J. Liq. Chromatogr., 13, 239 (1990).

4. M. D. Greaney, D. L. Marshall, B. A. Bailey and I. N. Acworth, J. Chromatogr., 622, 125 (1993).

5. A. Ajima, T. Nakagawa and T. Kato, J. Chromatogr., 494, 297 (1989).

6. T. Sakai, Y. Gao, N. Ohno and N. Ura, Chem. Lett., 1991, 163.

7. A. Jaramillo, S. Lopez, J. B. Justice, Jr., J. D. Salamone and D. B. Neill, Anal. Chim. Acta, 146, 149 (1983).

8. T. Yao, Y. Matumoto and T. Wasa, J. Flow Injection Anal., 4, 112 (1987).

9. L. Campanella, M. P. Sammartino and M. Tomassetti, Anal. Lett., 22, 1389 (1989).

10. M. Masoom, Anal. Chim. Acta, 214, 173 (1988).

11. B. L. Ruiz, E. Dempsey, C. Hua, M. R. Smyth and J. Wang, Anal. Chim. Acta, 273, 425 (1993).

12. E. Tamiya, Y. Sugiura, E. N. Navera, S. Mizoshita, K. Nakajima, A. Akiyama and I. Karube, Anal. Chim. Acta, 251, 129 (1991).
13. K. Honda, K. Miyaguchi, H. Nishino, H. Tanaka, T. Yao and K. Imai, Anal. Biochem., 153, 50 (1986).

14. T. A. Patterson and J. W. Kosh, Biol. Mass Spectrom., 21, 299 (1992).

15. Y. Ikarashi, K. Ito and Y. Maruyama, Biol. Mass Spectrom., 20, 21 (1991).

16. P. A. Shea and M. H. Aprison, Anal. Biochem., 56, 165 (1973).

17. J. E. Smith, J. D. Lane, P. A. Shea, W. J. McBride and M. H. Aprison, Anal. Biochem., 64, 149 (1975).

18. F. Gorus and E. Schram, Clin. Chem., 25, 512 (1979).

19. L. Risinger and G. Johansson, Anal. Chim. Acta, 261, 435 (1992).

20. R. Puchades, A. Maquieira and L. Torro, Analyst [London], 118, 855 (1993).

21. M. D. Luque de Castro and M. Valcarcel, Anal. Chim. Acta, 261, 425 (1992).

22. D. Perez-Bendito and M. Silva, "Kinetic Methods in Analytical Chemistry", p. 71, John Wiley and Sons, New York, 1988.

23. T. G. Burdo and W. R. Seitz, Anal. Chem., 47, 1639 (1975).

24. T. Komatsu, M. Ohira, M. Yamada and S. Suzuki, Bull. Chem. Soc. Jpn., 59, 1489 (1986).

25. T. Hasebe, E. Hasegawa and T. Kawashima, Anal. Sci., in press.

26. T. Hara, M. Toriyama, H. Miyoshi and S. Syogase, Bull. Chem. Soc. Jpn., 57, 3009 (1984).

27. M. S. Abdel-Latif and G. G. Guilbault, Anal. Chim. Acta, 221, 11 (1989).

28. J. Hadjianestis and J. Nikokavouras, J. Photochem. Photobiol., 67, 237 (1992).

29. H. Ojima, Nippon Kagaku Zasshi, 79, 1076 (1958).

30. T. Hara, M. Toriyama and K. Tsukagoshi, Bull. Chem. Soc. Jpn., 56, 1382 (1983).

(Received October 11, 1996)

(Accepted November 11, 1996) 